\title{
Think-pair-share technique for improving students' writing at the eleventh grade
}

\author{
Siti Hikmatun Nazilah ${ }^{\mathbf{1}}$, Flora $^{\mathbf{2}}$, Ramlan Ginting Suka ${ }^{\mathbf{3}}$ \\ English Education Study Program, University of Lampung ${ }^{1,2,3}$ \\ ${ }^{1}$ hikmatunazilah00@gmail.com
}

\begin{abstract}
This research aimed to find out whether there is a significant difference in students' writing achievement after the implementation of Think-Pair-Share technique and to know the students' perception toward the implementation of the technique. One group pretest and posttest design and one-shot case study design were the approaches of this research. The instruments were writing tests and questionnaire. The result shows that there is a significant difference in students writing achievement on analytical exposition text after the implementation of Think-Pair-Share technique. The evidence can be seen from the result of analysis where the significant value is .000 , the comparison between t-value and t-table $(9.696>2.034)$, and the mean of the score in pretest and posttest which increase 9.4 points. Furthermore, the results of the investigation on students' perception were also found that the students had a positive perception since the gained percentage is $80,22 \%$.
\end{abstract}

Keywords:Think-Pair-Share technique, writing achievement, analytical exposition text, perception

\section{INTRODUCTION}

Writing includes in a productive skill which represents personal ideas in form of a written text. Not only expressing the writer's feel and idea, but writing should be concerned to the way the message are conveyed as well. It is in line with Nunan (2003) who states that writing is the mental work of inventing ideas, thinking about how to express ideas, and organizing them into statements and paragraph that will be understood by a reader clearly. Shifting the abstract thought to the more concrete form of readable and understandable text is the main activity in writing. Additionally, writing involves both physical and mental act. Therefore, Graham et al (2005) stated that writing is considered as the skill that very difficult, complex, and challenging to master.

For the students, writing is an effortful task Salma (2015). Inventing and organizing the idea can be a hard thing to do for the students. Moreover, Mahmudah et al (2016) analyzed the students writing in MAN 2 Padang and found that there are problems related to grammar, vocabulary, diction, punctuation, and spelling in students' writing. At the same time, the students also think that writing is difficult and they have so many problems in doing writing. In general, Indonesian students' writing ability is very low. The similar problems in writing also happened to the students in SMAN 1 Negerikaton. The students had low motivation which affect to their ability 
towards writing. At the same time, the technique used by teacher was conventional technique and teacher centered learning which are not sufficient to boost students' motivation and to teach writing. Therefore, to help the students in learning writing, teacher should choose technique that appropriate with students' problems and needs.

Due to overcome the students' problem in writing, Think-Pair-Share can be a good technique to master writing analytical exposition text. According to Tint and Nyut (2015) Think-Pair-Share is a technique which prompts the students to reflect on a given issue or problem and share their thinking with others. Think-Pair-Share would be a suitable technique to be implemented in writing analytical exposition text. According to Lyman (1987), there are three stages in this technique, those are: 1) think which is done individually, 2) pair which is working cooperatively to compare the students' thought, and 3) share which is sharing the students' thought to the class. Stages in Think-Pair-Share techniques encourage the students to brainstorm their idea with the others after they reflected on the topic individually. In sum, Think-Pair-Share is a technique that allows the students to work individually and continue in a group work to collaborate their thinking.

Regarding the issue above, a lot of researches have conducted to find the effect of Think-PairShare technique in teaching English especially in teaching writing. A research conducted by Sampsel, in Irwandi (2018), analyzed the TPS technique and its effect on students' confidence in learning. The study found the improvement of students' participation, students' explanation, and students' comfort and confidence, and their contribution in class discussion. Siburian (2013) conducted a qualitative and quantitative research to see the students' improvement in writing descriptive text after the implementation of Think-Pair-Share technique. The result stated that the students' writing ability dramatically increased, besides, based on the result of the observation, the students gave their positive attitude and response during the implementation of the technique. In line with the previous research, Sahardin et al (2015) Found TPS had helped the tenth grade students of senior high school in Banda Aceh to improve their ability in writing descriptive text especially in the aspects of organization, vocabulary, and content.

Besides, considering students' point of view about the implementation of Think-Pair-Share technique is also important to see the appropriateness of the technique itself. Efron (1968), who proposed the theory of perception, states perception is the primary cognitive contact of person with the world around him. If the students think that the technique is perceived positively, it will boost the students' motivation and encourage them to learn actively and seriously. Kharisma and Hidayati (2018) state that asking students' perception about the way teacher teaches them will provide a connection about what the students' need for their learning activity. Hence, students' perception plays an important role in students' learning especially in English learning.

In brief, the procedures of Think-Pair-Share technique for teaching writing Analytical exposition text are: 1) the teacher reminds the students briefly about the structure, language features, and aspects of writing that should be considered in students' writing, 2) the students are asked to look at an issue in form of a statement provided by the teacher in form of a picture. 3) the students are asked to think and reflect the given issue individually, 4) after having their first draft, the students are asked to work together with their pair for sharing their opinion about the issue and making an analytical exposition text, 5) the teacher asks the representative of each 
pair to share their result of writing to the other students,6) after sharing the result of writing, the students will give suggestions and critics related to aspects of writing, etc.

Based on the problems above this research the question to be formulated are: 1) whether the implementation of Think-Pair-Share technique gives a significant difference on students' writing achievement and 2) the students' perception toward the implementation of the technique.

\section{METHODS}

This research was conducted to analyze the significance difference of students' achievement in writing analytical exposition text after the implementation of Think-Pair-Share technique. Besides, this research also tried to find out the students' perception towards the implementation of the technique. In order to answer the questions, this research used quantitative approach with the approach used are one group pre-test and post-test design (TI X T2) and One Shot Case Study (X T) (Setiyadi, 2018).

\section{Participants}

In this research, population is the second grade of the students in SMAN 1 Negerikaton in academic year 2020/2021. The second grade students are divided into 5 classes, 3 classes are science class and 2 classes are social class. Meanwhile, the researcher chose one class of sample as the representative. The sample is the students in XI IPA 2 class which consists of 34 students. The sample was chosen by using random sampling so that all the population class has the same opportunity to be research sample.

\section{Instruments}

The first instrument used to gain the data is writing test. The aim is to find out the students' achievement before and after the treatment was conducted. In addition, there are two kind of tests, those are pre-test and post-test. The pre-test would be given in the beginning of the meeting to see the students' initial achievement in writing. Then, the posttest was administered after the students are thought by Think-Pair-Share technique to indicate the difference of the students writing achievement. Both the tests had a similar instruction which is to make an analytical exposition text. However, the given situation or context was different.

\section{Data Analysis}

In order to get the complete result, the researcher analyzed the data through some steps: 1) calculating the mean of the pre-test and posttest; 2) analyzing the data using the Paired Sample $T$-Test in SPSS version 20 to see the significant difference of the students' writing achievement; 3) finding out the result of the questionnaire by computing the percentage of the gained score; 4) classifying the students' level of perception towards the implementation of Think-Pair-Share technique using the following criteria: 
Table 1. Criteria of Questionnaire

\begin{tabular}{|cl|}
\hline Percentage & \multicolumn{1}{c|}{ Criteria } \\
\hline $\mathrm{Pc} \geq 85 \%$ & Very positive \\
\hline $70 \leq \mathrm{Pc} \leq 84$ & Positive \\
\hline $55 \leq \mathrm{Pc} \leq 69$ & Moderate \\
\hline $40 \leq \mathrm{Pc} \leq 54$ & Negative \\
\hline $\mathrm{Pc} \leq 39$ & Very negative \\
\hline
\end{tabular}

(Ratminingsih, Artini, and Padmadewi, 2017)

\section{RESULTS AND DISCUSSION}

\section{Result}

\section{Result of Students' Writing Achievement}

In students' work on pretest, it indicates that some errors are found in relation to the aspects of writing. The errors are dealing with the content which was not elaborated well and the lack development of the idea. Likewise, some of inappropriate capitalizations and unsuitable word choices also existed in some part of the text. However, based on the result of students' work in posttest, it shows an adequate development of the topic and sufficient details as the supporting idea. Although there are some errors found in term of mechanics and grammar, but the students' pretest was considered better compared to the pretest. Proving the improvement from the representative, the following table is the comparison between the students' score in pretest and posttest.

Table 2. Distribution of Students' Score in Pretest and Posttest

\begin{tabular}{|c|c|c|c|c|c|c|}
\hline \multirow[b]{2}{*}{$\begin{array}{c}\text { Interval } \\
\text { Score }\end{array}$} & \multicolumn{3}{|c|}{ Pretest } & \multicolumn{3}{|c|}{ Pretest } \\
\hline & $\begin{array}{c}\text { Number of } \\
\text { Student }\end{array}$ & Percentage & Mean & $\begin{array}{c}\text { Number of } \\
\text { Student }\end{array}$ & Percentage & Mean \\
\hline $50-54$ & 6 & $17,6 \%$ & \multirow{9}{*}{62,07} & 0 & 0 & \multirow{9}{*}{71,47} \\
\hline $55-59$ & 8 & $23,5 \%$ & & 0 & 0 & \\
\hline 60-64 & 9 & $26,5 \%$ & & 7 & $20,6 \%$ & \\
\hline 65-69 & 5 & $14,7 \%$ & & 7 & $20,6 \%$ & \\
\hline $70-74$ & 4 & $11,8 \%$ & & 10 & $29,4 \%$ & \\
\hline $75-79$ & 1 & $2,9 \%$ & & 6 & $17,6 \%$ & \\
\hline $80-84$ & 1 & $2,9 \%$ & & 3 & $8,8 \%$ & \\
\hline $85-89$ & 0 & 0 & & 0 & 0 & \\
\hline $90-95$ & 0 & 0 & & 1 & $2,9 \%$ & \\
\hline & 34 & 100 & 62,07 & 34 & 100 & 71,47 \\
\hline
\end{tabular}

After the pretest and posttest were administered, the results of pretest were compared with the results of posttest in order to analyze the difference of students' writing achievement. From the result of the students' score in writing test, it indicates that there is an increase for about 9 points 
after Think-Pair-Share technique was implemented to teach writing. The mean score improved from62,07in pretest to 71,47 in posttest. Henceforth, to know the significant level of students writing improvement, the data were analyzed using Paired Sample T Test in SPSS version 20. The following table presents the result of the analysis:

Table 3. T-Test Result of the Hypothesis Analysis

\begin{tabular}{|c|c|c|c|c|c|c|c|c|}
\hline \multicolumn{9}{|c|}{ Paired Sample Test } \\
\hline & \multicolumn{5}{|c|}{ Paired Differences } & \multirow[b]{4}{*}{$\mathrm{t}$} & \multirow[b]{4}{*}{ Df } & \multirow{4}{*}{$\begin{array}{c}\text { Sig. } \\
(2- \\
\text { tailed })\end{array}$} \\
\hline & \multirow[b]{3}{*}{ Mean } & \multirow{3}{*}{$\begin{array}{c}\text { Std. } \\
\text { Deviation }\end{array}$} & \multirow{3}{*}{$\begin{array}{l}\text { Std. } \\
\text { Error } \\
\text { Mean }\end{array}$} & \multicolumn{2}{|c|}{ 95\% Confidence } & & & \\
\hline & & & & $\begin{array}{r}\text { Interva } \\
\text { Diffe }\end{array}$ & $\begin{array}{l}\text { of the } \\
\text { ence }\end{array}$ & & & \\
\hline & & & & Lower & Upper & & & \\
\hline Pair & & & & & & & & \\
\hline $\begin{array}{l}\text { PRETEST } \\
- \\
\text { POSTTEST }\end{array}$ & 9.39706 & 5.65120 & .96917 & 7.42526 & 11.36886 & 9.696 & 33 & .000 \\
\hline
\end{tabular}

Based on the table, it can be noticed that the significant value is .000 . It means that $\mathrm{H}_{1}$ is accepted since .000 is lower than 0.05 . The significant value proves that the implementation of Think-Pair-Share technique gave the significant effect and influenced the students writing achievement. Besides, the comparison between t-table and t-value also shows the significant difference on students' writing achievement after they were thought by Think-Pair-Share technique since 9.696>2.034, t-value is higher than t-table. Moreover, considering the mean of writing test, by comparing the mean of the pretest $(62,07)$ and posttest $(71.47)$, it is found that there is also an increase for about 9.4 points. In addition, there was an improvement of students writing achievement after being taught by Think-Pair-Share technique. In brief, the alternative hypothesis which is there is a significant difference of students' writing achievement after the implementation of Think-Pair-Share technique in teaching analytical exposition text of this study was accepted.

\section{Result of the Students' Perception}

The questionnaire covered four topics on learning English: the students' feeling after the implementation of the technique in the classroom, the effectiveness of the technique compared to the other, the benefits of the technique related to the writing ability, and the improvement of students' writing ability after the implementation of the technique, modified from Ma'arif and Aslihah (2017). Therefore, the result of questionnaire was divided into four parts as follows:

Table 4. The Gained Score from the Questionnaire

\begin{tabular}{|c|c|c|c|c|}
\hline No & Questionnaire Section & $\begin{array}{l}\text { Max } \\
\text { Score }\end{array}$ & $\begin{array}{c}\text { Gained } \\
\text { Score }\end{array}$ & Percentage \\
\hline 1 & Implementation of Think-Pair-Share technique & 272 & 220 & $80,88 \%$ \\
\hline 2 & The effectiveness of Think-Pair-Share technique & 272 & 217 & $79,78 \%$ \\
\hline 3 & The benefit of Think-Pair-Share technique & 544 & 432 & $79,41 \%$ \\
\hline
\end{tabular}




\begin{tabular}{|ccrrr|}
\hline 4 & The improvement of students' writing ability & 272 & 222 & $81,62 \%$ \\
\hline Total & $\mathbf{1 3 6 0}$ & $\mathbf{1 0 9 1}$ & $\mathbf{8 0 , 2 2 \%}$ \\
\hline
\end{tabular}

The table shows that the percentage of each section of questionnaire, related to four topics in learning English, are all above 70\%. Based on the criteria of perception, it can be concluded that the students had positive perception toward each section of the questionnaire. Moreover, by computing all the gained score and maximum score, it is obtained $80,22 \%$ which means that the students had a positive perception on the implementation of Think-Pair-Share technique.

The positive perception of the students toward the implementation of Think-pair-Share technique was created since the procedure/stages of writing can be easily associated with the steps of Think-Pair-Share technique. In think time, the students were allowed to do the first and second stage of writing which is planning by reflecting and making notes about the topic. In pair phase, the students did the further stages of writing which are drafting and editing by discussing with their friends. In addition, for the share time, the final version of the students writing was presented to the whole class. By completing those processes unconsciously the students followed the appropriate procedure of writing which encourages them to compose a good writing. Besides, in the same time, they had also a joyful learning which boosts their active involvement in classroom. Hence, the students' positive perception on the use of Think-PairShare technique added the good quality of learning.

\section{Discussion}

\section{The Students' Different Achievement in Writing}

The answer of the first research question is discussed in this heading by referring to the result of the study. The result of the discussion would state whether the implementation of Think-PairShare technique can give a difference and make an improvement on the students' writing achievements. The treatment, the implementation of Think-Pair-Share technique, was successfully administered using WhatsApp Group Discussion. The writing tests were given to the students at the beginning and the end of the treatments to find out whether there is an improvement in the students' writing achievement. A similar situation using WhatsApp group video call was managed to conduct the tests; however, the given topics were different.

Furthermore, after the data was collected and analyzed, the comparison between the students' score in pretest $(62,07)$ and posttest $(71.47)$ was considered 9.4 points increase. Likewise, the calculation of the difference using Paired Sample T-Test using SPSS version 20 shows that the $\mathrm{t}$-value gained 9.696 which is higher than t-table 2.034. The same formula was used to find out the significant level and 0.00 was obtained as the significant level of the pretest and posttest. Hence, all the evidence proved that the implementation of Think-Pair-Share technique significantly improved the students' achievement in writing.

The finding of this research supports the result of the study conducted by Siburian (2013) who did qualitative and quantitative research to see the students' improvement in writing descriptive text after the implementation of Think-Pair-Share technique. The result stated that the students' 
writing ability is dramatically increased. It can be seen from the mean of the mark which got 66,4 for the first test, 78,1 for the second test, and 87,5 for the third test.

In another study, the finding also supports research conducted by Rahmawati (2017). She investigated the implementation of Think-Pair-Share technique in writing narrative text at the tenth grade of SMAN 1 Brojonegoro. The result shows that the use of Think-Pair-Share technique can improve the students' writing skills, especially in narrative text. Moreover, this technique encourages students' active involvement in the classroom since they have to discuss with their partners about the materials that is learned.

A study conducted by Abidah and Sabur (2018) was also supported by the finding of this research. They conducted a study about the implementation of Think-Pair-Share technique in teaching writing focused on descriptive text in the tenth grade of SMAN 2 Tangerang. Then, the result shows a significant increase. It can be seen from the score of post-test in the experimental class that is 70.67 which were higher than the control class 67.23.

Based on those present studies about the implementation of Think-Pair-Share, it proved that Think-Pair-Share technique was beneficial for students in learning English especially writing. It can be seen from the improvement of the mean of the pretest and posttest which was conducted in present studies.

\section{Students' Perception toward the Implementation of Think-Pair-Share Technique}

This section presents the discussion of the questionnaire result for answering the second research question which is about the students' perception toward the implementation of ThinkPair-Share technique. Considering students' point of view is important since it remains a reality of the English learning classroom and it revealed their feeling during the process of teaching and learning in the implementation of Think-Pair-Share. Therefore, the result of this questionnaire supported the research finding.

The questionnaire was in form of a close-ended questionnaire completed by the Linkert Scale, ranging from strongly agree, agree, disagree, and strongly disagree. For computing the result, the score 4,3,2, and 1 were given for each possible choice, then, the gained score was divided into maximum score and transformed in form of a percentage. There were ten items of the questionnaire divided into five sections according to the topics on learning English.

The questionnaire, designed in this research, used closed-ended questionnaire approach. The students' response was restricted into four possible answers: very agree, agree, disagree, and very disagree. Consequently, the gained data from the questionnaire was limited since the students could not give depth responses about the reason why do they agree with the statements. However, though there was a limitation on the response, the obtained data of the questionnaire consist adequate information to find out the students' perception toward the implementation of Think-Pair-Share technique.

The result of the questionnaire can be seen in table 4.7. It proved that most of the students had a positive perception of four sections of the questionnaire. It can be seen from the percentage of each section obtained more than $70 \%$ which means positive based on the criteria of perception. The students thought that the use of Think-Pair-Share technique motivated and helped them 
more compared to the other technique. Besides, it was also beneficial for them to do better in the aspect of writing especially for content. Moreover, besides writing, the students also thought that Think-Pair-Share also allowed them to read more. Generally, just like the result of the last item, the students were agreed that the use of Think-Pair-Share technique can improve their writing.

However, there are 1-6 students who chose disagree on almost every item. A higher percentage for disagreeing was found in the eighth item which is about the mechanics. It happened because most of the students mostly did not give more attention to mechanics when they discuss and write. It can be seen from the result of their work which mostly had errors in capitalization, paragraphing, etc. The disagreement about the advantages of Think-Pair-Share technique in other items also happened because some problems were found when the technique was implemented which made some students could not join the discussion maximally. The problem mostly faced by the students was about internet connection. It caused some students missed some discussions and they had to spend more time for understanding and finishing their discussion with their friends.

The finding of this second research question supports previous research conducted by Ma'arif and Ashlihah (2017). They did qualitative descriptive research with the English education students as the sample. The investigation of students' opinions about the use of Think-PairShare resulted that the students have a positive opinion with $84.81 \%$ of students were responding positively. Besides, in one of his research findings for Think-Pair-Share technique, Siburian (2013) also found that based on the result of the observation, the students gave their positive attitude and response during the implementation of Think-Pair-Share technique. Moreover, students also said Think-Pair-Share technique had helped them and they agreed with the application of the technique in writing class.

Based on the discussion of the finding, it can be concluded that the use of Think-Pair-Share technique gave a good effect on students for learning writing and improving their writing.

\section{CONCLUSIONS AND SUGGESTIONS}

Considering the result and the discussion of the gained data, it can be concluded that The implementation of Think-Pair-Share technique is significantly effective to improve the students' writing. It is proven by the increase in students' mean scores and the result of the analysis using Paired Sample T-Test. Each stage of Think-Pair-Share technique could encourage the students to involve and give their best performance on the process of writing by reflecting on the topics, discussing with their friends, and presenting their works to the class. Similarly, during the activity, the students were giving and receiving input from their friends. By those inputs, it helped the students to compose an adequate development of the topic and sufficient details as the supporting idea. Therefore, this technique is effective to help the students brainstorm and enlarge their idea with their friends. In addition, By considering the percentage of the obtained score of the questionnaire, $80,22 \%$, it means that the students had a positive perception toward the implementation of Think-Pair-Share technique. The application of Think-Pair-Share technique made the learning process enjoyable for the students. The students' high motivation makes their better understanding of writing possible. In other words, the students' positive 
perception means that the use of Think-pair-Share technique is effective enough for teaching writing. However, the reason and solution for the students who still do not agree with the use of the technique need to be considerated since it is related to the students' needs.

Therefore, as the implication of this study, there are some suggestions for English teacher. First, as the facilitator, the teacher should provide learning technique which encourages the students to learn actively. Therefore, Think-Pair-Share technique is highly recommended to be implemented as a variety of techniques to teach writing since this study has shown that the implementation of Think-Pair-Share was effective to improve students' achievement in writing. Second, it is also important for teacher to explain the concept of Think-Pair-Share technique in a brief and simple way to make sure that there is no miss understanding among the students. Last, it is necessary for the teacher to consider the students' point of view to see the students' needs and the weaknesses of the technique as the objective data to evaluate the process of teaching and learning activities.

However, this research is not without limitations. Therefore, for further research, the researcher proposed some suggestion in order to make a better quality of research. Firstly, further research can try to investigate the implementation of Think-Pair-Technique to different levels of students, different skills, or different types of text since study was conducted at the senior high school level and limited only in the scope of writing.Secondly, it is also suggested to use the interview or focus group discussion as the variations of technique to collect the data for students' perception so that the data will be deeper and more reliable. Third, though the students' perception towards the implementation of Think-Pair-Share technique was positive, there were still some students who do not agree with the use of the technique. Therefore, the further researcher could evaluate and find out the solution on how to make the students enjoy the technique that fits their needs.

\section{REFERENCES}

Abidah and Sabur. (2018).The effect of think pair share (tpr) technique to improve students' writing skill on descriptive text at tenth grade of SMAN $2 \mathrm{Kab}$. Tangerang in academic Year 2018/2019.Foremost Journal, 1(1), 36-42.

Efron, Robert. (1968). What is perception? Proceeding of the Boston colloquium for the philosophy of science. Boston: Springer Link.

Graham, S., Harris, K.R., and Mason, L. (2005).Improving the writing performance, knowledge, and self-efficacy of struggling young writers: the effects of self-regulated strategy development with and without peer support.American Educational Research Journal, 43(2), 295-340.

Irwandi, I.H. (2018). Improving students' reading skill through think-pair-share (TPS) technique.Journal of English Language Teaching and Linguistics, 11(2), 1-7.

Kharisma, I., and Hidayati, L. A. (2018).Students' perception in learning English using cooperative learning activity.Professional Journal of English Education, 1(3), 207-216. 
Lyman, F. (1987).Think-pair-share: an expanding teaching technique. MAA-CIE Cooperative News, 1(1), 1-2.

Ma'arif, I. B., and Ashlihah.(2017). Students' positive response through think pair share strategy on English speaking skills.ELTIN Journal, 2(2), 85-89.

Mahmudah, R. A., Rozimela, Y., and Saun, S. (2017). An analysis of generic structure in students' writing of an analytical exposition text at grade xi of MAN 2 Padang in the 2015/2016 academic year .Journal of English Language Teaching, 6(1), 84-93.

Nunan, D. (2003). Practical English language teaching. Singapore: McGraw- Hill.

Ratminingsih, N. M., Artini, L. P., and Padmadewi, N. N. (2017).Incorporating self and peer assessment in reflective teaching practices.International Journal of Instruction. 10(4), 165184.

Sahardin, R., Hanum, C. S., \&Gani, S. A. (2017).Using think-pair-share for writing descriptive texts.Studies in English Language and Education, 4(1), 54-63.

Salma, Umme. (2015). Problems and practical needs of writing skill in EFL context: an analysis of Iranian students of Aligargh Muslim University. IOSR Journal of Humanities and Social Science, 20(11), 74-76.

Setiyadi, Ag. B. (2018).Metodepenelitianuntukpengajaranbahasaasing: pendekatankualitatifdankuantitatif, edisi 2. Yogyakarta: GrahaIlmu.

Siburian, T. A. (2013). Improving students' achievement on writing descriptive text through think pair share.International Journal of Language Learning and Applied Linguistics World (IJLLALW), 3(3), 30-43.

Tint and Nyut. (2015). Collaborative learning types with think pair share technique. Computer Applications: An International Journal (CAIJ), 2(1), 1-11. 